\title{
OSCAR WILDE AND THE FREEDOM OF THE WILL
}

\author{
BY ANDREA SELLERI
}

\section{A LIBERTARIAN DETERMINIST?}

One's regret is that society should be constructed on such a basis that man has been forced into a groove in which he cannot freely develop what is wonderful, and fascinating and delightful in him. . . . It will be a marvellous thing — the true personality of man—when we see it. ${ }^{1}$

—Oscar Wilde, "The Soul of Man under Socialism”

Necessity ... is a magic web woven through and through us . . more subtle than the subtlest nerves yet bearing in it the central forces of the World-When we combat it, [it is] with the weapons of its own forging, and the assertion of liberty is only the claim that from certain forms of conscious volition certain results will inevitably follow. ${ }^{2}$

—Oscar Wilde’s Oxford Notebooks

Over the course of his career Oscar Wilde defended both of the main positions on the issue that David Hume called "the most contentious question of metaphysics": whether or not free will exists. ${ }^{3}$ On the one hand, his central ethical/political ideal that one's personality should be allowed to develop freely, first articulated in his American lectures and later more memorably in "The Soul of Man under Socialism," presupposes that free will is possible, and that political freedom is the basis of it. ${ }^{4}$ This ideal surfaces time and again when Wilde discusses moral issues, and even when he laments the absence of this type of freedom, as when in "De Profundis" he blames himself "for the entire ethical degradation I allowed you [Douglas] to bring on me," Wilde accepts that the power to direct one's actions is available in principle, though not always accessible in practice: "The basis of character is will-power, and my will-power became absolutely subject to yours." If he had not let himself be shackled, he implies, then he would have been free. 
On the other hand, several uncompromisingly deterministic statements can be found throughout Wilde's corpus, starting from his Oxford notebooks. Such statements are couched in a variety of terms, sometimes quasi-medical (action as the result of "nerves" and "fibres," a contention that changes little from the notebooks to Lord Henry's aperçus in The Picture of Dorian Gray), sometimes vaguely Gothic (as in the passage in "De Profundis" where he calls Douglas a "puppet worked by some secret and unseen hand to bring terrible events to a terrible issue"), sometimes broodingly existentialistic (as in the letter written after visiting his wife's grave, where he claims to have been "deeply affected - with a sense, also, of the uselessness of all regrets. Nothing could have been otherwise—and Life is a very terrible thing"). ${ }^{6}$ In such passages it is neither a question of making the right choices nor of getting rid of bad societal arrangements or personal entanglements: the very condition of possibility for freedom is denied.

What are we to make of the coexistence of these apparently incompatible attitudes? To date, most scholarship has tended to focus on one side of the matter (Wilde's fascination with determinism), trace it back to his interest in the sciences, and correlate it with his general disdain for conventional morality. The main source of evidence for these views is The Picture of Dorian Gray, especially the protagonist's musings on the biological basis of behavior. For example, Terri Hasseler and Michael Wainwright derive Dorian's meditations on the taints of his blood from his creator's engagement with contemporary theories of heredity, while Carolyn Lesjak reads the novel through atomic theory, and Caroline Sumpter connects Wilde's ethical thought to debates about evolutionism. ${ }^{7}$ Some interpretive consequences of this scientific genealogy are sketched by Terry Eagleton, who sees Wilde's early embrace of the unchangeable laws of biology as a prefiguration of his later aestheticism: "[T]he theory of heredity tells us that all action is pre-programmed, and thus liberates us from moral responsibility for our deeds into the freedom of pure contemplation." Roger Smith is on similar lines in arguing that the determinism of the theory of heredity "took some sting out of the moral imperative" for Wilde. ${ }^{9}$

All these are defensible considerations as far as they go, but it seems difficult to square them with Wilde's commitment to personal freedom, evident in his political statements and in the moral sides of his fiction alike. An attempt to address this "libertarian" side of Wilde is found in Philip Smith and Mark Helfand's commentary on his notebooks, where they assert that he rejected "Pater's paradoxical denial of free will in the name of scientific determinism" in favor of 
an "idealist, Hegelian aesthetic humanism" presupposing free will. ${ }^{10}$ Bruce Haley's less sweeping contention is that Wilde's engagement with science led to a theory of life as a "complex working towards freedom." ${ }^{11}$ To the best of my knowledge, however, the only critic who has made a sustained attempt to reconcile Wilde's deterministic leanings to the ideal of freedom underpinning his progressivism is Elisha Cohn, who argues that Wilde's acquaintance with "scientistic materialism" starting from 1874 ("the same year," she adds, "that thinkers like W. K. Clifford, John Tyndall and others began to interrogate concepts like human autonomy and consciousness") led him to develop a "neurological aestheticism" that "integrates the dandy's pleasure with the socialist's critique of exploitation without making an impossible demand for action." ${ }^{12}$

Cohn's attempt to take both sides of Wilde's thinking seriously is creditable, but a more capacious conceptual and evidential framework is required to do justice to his engagement with this topic, whose stakes were felt across a much wider spectrum than Cohn acknowledges. For one thing, the practice of "interrogating human autonomy and consciousness" had begun long before the sciences of Wilde's lifetime, having been part and parcel of philosophical discussions of the freedom of the will since antiquity, as he well knew. ${ }^{13}$ For another, as I will show, nearer Wilde's own time the theme in question was also a central concern for philosophy, jurisprudence, and the social sciences, as well as for literature. Wilde was certainly acquainted with at least some of the sources I discuss below, but my purpose is less to argue for a direct influence than to depict how these disciplines defined the terms and stakes of the question, the routes along which discussion proceeded and filtered through to an educated non-specialist such as Wilde. Directly or indirectly, the specificities of this longer humanistic intellectual history were bound to affect the significance of the problem for a classically educated late-Victorian man of letters at least as much as the increasingly specialized scientific research of the time did. ${ }^{14} \mathrm{I}$ will argue that, important as scientific concepts such as heredity and evolution undoubtedly were for this writer, this alternative tradition also mediates his engagement with this theme; and that this goes some way towards explaining its contradictoriness. First, however, let me establish why the freedom of the will mattered to Wilde. 
Given that nowadays the subject is seldom broached outside of philosophy departments, it may not be easy to appreciate how high the stakes of the relationship between freedom and necessity were for many educated Victorians; yet, as metaphysical questions go, this was something of a hot topic. ${ }^{15}$ To what extent our actions are determined by extrinsic factors, what those factors are, whether we can win any freedom for ourselves by individual or collective initiative-all these were aspects of a single debate which by Wilde's lifetime had involved not only a sizeable cohort of philosophers and theologians, but also many jurists and natural and social scientists; and as John Reed has shown in his Victorian Will, this was also a common topic in sermons, debates, semi-popular essays and novels throughout the period. ${ }^{16}$ One's position on the matter could affect one's ideas on such subjects as Protestant versus Catholic doctrine, political liberty, legal accountability, the morality of day-to-day interactions, and not least how novelists went about structuring plots (for example, what diegetic factors cause the development of the action) and explaining characters' motivations (how determined they are by their impulses, environment, inherited traits, upbringing, and so on). Reed shows that much Victorian literature thematizes a range of relevant concepts such as liberty, fate, action, and predestination in ways that, whether or not accompanied by explicit philosophizing, imply a position on the spectrum from belief in free will to determinism. He does not, however, tackle Wilde.

Indeed, most analyses of the relevance of this theme for Victorian literature have focused on more overtly philosophical novelists, most notably George Eliot and Thomas Hardy. But Wilde was, if anything, more consistently concerned with the subject than either; and while in his later years this feaster with panthers, irresponsible spender, nicotine addict, and plaintiff in hopeless and dangerous lawsuits had perhaps more reason than most to take a principled interest in what makes us act the way we do, his preoccupation with this issue was career-long. ${ }^{17}$ In fact, it was already taking shape in his time as an Oxford undergraduate (1874-78), when his study of a diverse group of thinkers who had dealt with the issue (Herodotus, Polybius, Herbert Spencer, Walter Pater) led him to frequent musings on various aspects of it: for example, whether it is "possible to ascertain the laws which govern the phenomena of human action," and conversely whether any such phenomenon is not explainable as the result of definite laws, and may therefore be considered free. ${ }^{18}$ While sometimes (as in the second 
epigraph reported above) he thoroughly embraces a deterministic position, elsewhere a rather more empiricist note is struck: "To adjust the balance between freedom and necessity . . . is the problem of the historian"- not of the philosopher. ${ }^{19}$

This divided attitude - on the one hand a fascination with deterministic explanations of action, on the other a desire to privilege observation of the concrete ramifications of the problem without pledging oneself to a definite theory - is also in evidence in the slightly later essay "The Rise of Historical Criticism," which Wilde wrote (and partly plagiarized) in the soon-to-be-dashed hope of obtaining a fellowship at his enduringly elusive alma mater ${ }^{20}$ In it Wilde endorses what he takes to be Aristotle's views on "the conflict of Free Will with general laws" $(C W 4,34)$. Wilde's Aristotle does not altogether deny free will, because "necessitarianism in its crude form [is] essentially a reductio ad absurdum of life," but he does admit that the will is "continually influenced by habits, education and circumstance; so absolutely modifiable ... that the good and the bad man alike seem to lose the power of free will; for one is morally unable to sin, the other physically incapacitated for reformation" (CW4, 34, 34).

These early documents do not reveal a special philosophical talent aside from Wilde's obvious cleverness: as theory, his formulations are often questionable (can necessitarianism in its "crude form" be false and at the same time one's will be "absolutely modifiable" by circumstance?) or under-elaborated (what would be required to make necessitarianism less crude?). They do, however, offer some important insights into his later career. Firstly, he clearly had a sustained interest in the question: reflecting on it was part of his forma mentis. Secondly, the problem was for him, as for most nineteenth-century intellectuals, inextricably bound to causality: to the extent that a human act could be shown to have been caused by some extrinsic element, to that extent it was certainly not free; conversely, if freedom was to be found anywhere, it was in acts that resisted causal explanations. ${ }^{21}$ Thirdly, he believed that this question had a purchase on real life, morality, and by extension on art, "the perfect expression of life" (CW4, 137).

Lastly, his thinking evidently oscillated between competing strains. This should be no stumbling block for the strand of scholarship engaged in recuperating a philosophical Wilde, but rather a starting point. ${ }^{22}$ Wilde's acuity did not emerge as much in theorization as in laying bare the points at which the underlying assumptions of others' theories bumped against observation. I suggest that Amanda Anderson's characterization of George Eliot's fiction as "living theory" could just 
as well be applied to Wilde's work, in the sense that both writers, in their vastly different ways, aimed at a form of fiction capable of tackling non-reductively the complexities and contradictions of philosophical problems as they present themselves in actual life and experience, without streamlining them in the approved manner of philosophical discourse. ${ }^{23}$

Mine is an attempt to take Wilde seriously as a literary thinker in this sense, examining his engagement with a philosophical topic that he clearly regarded as important, and contextualizing it within the discursive tradition most preeminently engaged with that topic. My argument in the next and longest section, thus, is partly historical and partly interpretive. I will pursue the dynamic relations between Wilde's works and four distinct areas of a broadly conceived humanistic tradition centered on philosophy, in order to show that the specific stakes, tensions, and argumentations which this tradition developed around the general problem of the freedom of the will are an implicit substrate for Wilde's literary approaches to a range of related themes; furthermore, that their literariness bestows on said approaches a significant element of originality. By thus proceeding I hope to add nuance to our understanding of what the freedom of the will meant to Wilde, prepare the ground for my close reading of The Picture of Dorian Gray, and articulate a specific sense in which Wilde can be classed as a skeptic.

\section{THE PHILOSOPHICAL TRADITION AND WILDE'S OEUVRE}

Since the problem of the freedom of the will emerged in antiquity philosophers have devised countless variations on it, some of them highly technical, but the two fundamental views are intuitive enough: (a) the claim that human beings are endowed with free will-a position usually labeled "indeterminism" or (as I have) "libertarianism"; (b) the denial of the above-usually known as "(hard) determinism" nowadays, and as "necessitarianism" in the period at hand. ${ }^{24}$ Versions of these views were brought to bear on many branches of philosophy as well as on adjacent discursive clusters, acquiring in each case a distinct set of stakes and tensions. As will be seen, Wilde's engagement with the topic was conditioned by this intellectual context, to the point that for each major side of the issue there are parallels in his writings. My choice to focus on a single work of Wilde's in each subsection is due to ease of exposition and does not imply that this lens could not be profitably applied to other parts of his oeuvre-rather the opposite. 
At its most abstract, the problem of the freedom of the will hinges on the ontological question of whether the law of causality affects mind and matter differently. Experience tells us that physical matter responds predictably to stimuli (if I let a pin drop, the pin cannot choose not to drop-likewise if I fall down a cliff); but indeterminism regards the mental realm as constituting at least a partial exception to the law of cause and effect, whereas determinism does not admit any such distinction. For the indeterminist, although we are affected by external conditions, there exists a "point of freedom" beyond which our responses to them are unconstrained; for the determinist, in turn, every occurrence, from the simplest physical instances of action and reaction to the higher cognitive processes that direct humans' actions and thoughts, is the inevitable result of the convergence of suprasubjective determinants (variously called forces, processes, impulses, or motivations depending on the ambit where they occur). ${ }^{25}$

A typical nineteenth-century framing of the question was to ask whether one can distinguish between how causality operates in the realm of the physical (widely understood as deterministic since the scientific revolution) and in that of the mental (which Christian traditions had largely regarded as possessing a degree of freedom). ${ }^{26}$ Necessitarians' collapsing of the distinction between the physical and the mental broke away from the religious framework altogether. As John Stuart Mill sympathetically glosses the position, "volitions do, in point of fact, follow determinate moral antecedents with the same uniformity, and (when we have sufficient knowledge of the circumstances) with the same certainty, as physical effects follow physical causes. ${ }^{.27}$ On the Continent, such a position had a longer history, carried on the long wave of the reactions to René Descartes's ontological dualism. This tradition included the use of paradoxical illustrations: for example, in a letter written in 1674, Baruch Spinoza maintains that if a stone falling down a slope were conscious, it would believe that it was moving of its own free will. ${ }^{28}$ Arthur Schopenhauer's 1838 Essay on the Freedom of the Will similarly imagines water as self-conscious and thus able to say to itself that it freely chooses to boil or freeze when the appropriate temperatures happen to be reached..$^{29}$ The implication is that though our minds may feel free, we are nonetheless material, and therefore as determined as any other object. 
While this is admittedly rather remote from the world of Bunbury, Wilde mentions all these philosophers in his correspondence, and his awareness of the controversy over the tenability of the distinction between the physical and the mental is apparent from the Oxford notebooks. With this in mind, consider the following passage, presented by Richard Le Gallienne in his memoir The Romantic '90s as the transcript of a story Wilde told towards the beginning of that decade:

Once upon a time there was a magnet, and in its close neighbourhood there were some steel filings. One day two or three filings felt a sudden desire to go and visit the magnet, and they began to talk of what a pleasant thing it would be to do. Other filings nearby overheard their conversation, and they, too, became infected with the same desire. Still others joined them, till at last the filings began to discuss the matter, and more and more their vague desire grew into an impulse... . Meanwhile, without their having noticed it, they had been involuntarily moving nearer to the magnet, which lay there quite still, apparently taking no heed of them. . . . Some were heard to say that it was their duty to visit the magnet. . . . Then, at last, the impatient ones prevailed. . . . And then in one unanimous mass they swept along, and in another moment were clinging fast to the magnet on every side. Then the magnet smiled - for the steel filings had no doubt at all that they were paying that visit of their own free will. ${ }^{30}$

Although no empirical evidence has surfaced to confirm Wilde's authorship, Le Gallienne's attribution seems plausible, both for stylistic reasons (the story's diction and structure are very similar to Wilde's roughly contemporary "Poems in Prose") and because its paradoxical approach, while strikingly similar to Spinoza's and Schopenhauer's thought experiments, is also humoristic in a distinctly Wildean way. ${ }^{31}$

For all its lightness of touch, this story or parable carries a considerable philosophical heft. In it the phenomenological trappings of free will are bestowed on entities - the steel filings-whose "acts"-for instance, their movement towards the magnet-are entirely determined by extrinsic forces, for instance, magnetism. The filings thus become humanity's representatives, equipped with a consciousness of self, affective dispositions that become motivations (a "desire" growing into an "impulse") and complex ethical notions ("duty"). This anthropomorphization, however, can only confer on them the illusory self-perception of being free agents, not free agency itself: for the filings, and by implication for the rest of us, the latter is impossible. 
The story, then, may well be taken as embracing Spinoza's and Schopenhauer's deterministic position that there is no essential difference between our actions and the physically motivated occurrences to which stones, water and steel filings are subject. And yet, Wilde's early skepticism about necessitarianism on the grounds that it is a reductio ad absurdum of life (surely an apt description of this story) does give one pause. The implied outlook of this micro-fiction, with its quasiSwiftian satire of human pretensions to freedom, may not exactly be wrong, but its wryness does suggest that something may have been lost in this "reduction," namely the flesh that human life puts on the bare bones of theory. That, however, is no longer the philosopher's domain, but the historian's, as the young Wilde suggested-and also, I will argue, the artist's.

\section{INTUITION AND OBSERVATION: POEMS}

The mind/matter divide is intimately connected to an epistemological paradox that had been articulated long before Wilde: that, as Samuel Johnson neatly puts it, "all theory is against the freedom of the will; all experience for it." 32 There is, the argument goes, an irreconcilable discrepancy between the way we perceive the world around us and our usual sense of ourselves. Events in the external world are typically perceived as links in a causal sequence (hence determined), yet we tend to regard our own decisions as unconstrained (hence free), and ourselves as able to imagine different courses of action, weigh them against one another, choose one, and carry it out. ${ }^{33}$ Whether any given act will be regarded as free or as determined, then, will be affected by whether one's focus is the actant's subjective self-perception or the act's objective embeddedness in a causal sequence or other.

The distinction between the realms of the mental (potentially free) and the physical (definitely determined) can thus be regarded as a problem of perspective-seeing from inside versus seeing from the outside-which is in turn neatly mappable onto the divide between the two foremost Victorian epistemologies: intuitionism (epitomized by the Philosophy of Common Sense of Thomas Reid) and inductivism (whose tenets were codified by Mill). Intuitionists' privileging of the view from inside led them to support free will, which they did through various versions of William Hamilton's argument that our feeling of freedom is a good enough basis to believe that we are free. ${ }^{34} \mathrm{~J}$. A. Froude puts this forcefully: "[a] conviction assures us that there is somewhere a point of freedom. What that point is, where other influences terminate and 
responsibility begins, will always be of intricate and often impossible solution. But if there is such a point at all, it is fatal to necessitarianism, and man is . . . an exception in the order of nature." 35

This view was resisted by necessitarians (who included sociologists in polemic with individual-centric historians both Whig and Tory). Their denial of free will was grounded on a broadly inductivist epistemology, onto which Positivist influences were effortlessly grafted from the 1840s on. As Charles Bray puts it in distinctly Comtean phraseology, "the self of the conscious being is nothing but an object of observation, known only as everything else is known, by the chain of necessary antecedents and consequents"- that is, from the outside. ${ }^{36}$ To the difficulty often remarked on by free will advocates that human actions typically appear more irregular than physical processes, suggesting that there are limits to causation, the polymath H. T. Buckle (whom Wilde read) replied, echoing Mill: "If we were acquainted with the whole of the antecedents and with the laws of their movements . . . we could with unerring certainty predict the whole of their immediate results." ${ }^{37}$ For Victorian necessitarians, in short, there is no such thing as a "point of freedom": the seeming irregularity of human actions is merely an illusion resulting from our imperfect knowledge of their determinants, too subtle and numerous to be wholly apprehended, but decisive nonetheless.

This last point is crucial to Wilde's aesthetics, and I will return to it in my reading of The Picture of Dorian Gray. But the central conundrum informing these debates, for instance the discrepancy between how subjective experience and objective observation view human action, is also a central theme in two of Wilde's poems: "Helas!" from the 1881 Poems, and "The Harlot's House," published in the Dramatic Review in 1885. The former's lyrical cry is elicited by the breaking of the poetic subject's illusion of freedom as an epiphanic moment prompts him to see himself as an externally determined object rather than an autonomous subject:

To drift with every passion till my soul

Is a stringed lute on which all winds can play:

Is it for this that I have given away

Mine ancient wisdom, and austere control ${ }^{33}$

In this sonnet, aestheticism's promise of freedom through art turns out to reveal a more fundamental kind of slavery. The notion of "being played" like an instrument to signify somebody's lack of control (a 
theme with illustrious literary antecedents, from William Shakespeare's Hamlet to Samuel Taylor Coleridge's "The Aeolian Harp," and with several parallels in Wilde's corpus) here symbolizes the poetic subject's realization that no matter what he does, he remains a thing acted on by external forces.

A similar figure, the puppet, is the central image of the Symbolistinspired "The Harlot's House," which records the impressions of somebody passing by (or possibly heading towards) said establishment one night, accompanied by a lover, and stopping to look at the moving shapes of the revelers silhouetted against the window curtains. The speaker/observer perceives these human beings as pseudo-human objects moved by some external force:

Like strange mechanical grotesques,

Making fantastic arabesques,

The shadows raced across the blind.

$(C W 1,160)$

The poem insists quite emphatically on the thing-like quality of people when seen from outside by someone who does not share their determining passions and is thus able to look at them more objectively than they do themselves. Thus "wire-pulled automatons" $(C W 1,160)$ and "clockwork puppet[s]" $(C W 1,161)$ succeed one another in an estranged simulacrum of the living creatures they in fact are. At one point "a horrible Marionette" comes out and smokes a cigarette, "like a live thing" $(C W 1,161)$. Elsewhere the patrons are compared to inert matter that was formerly alive: "black leaves wheeling in the wind" (CW1, 160), "skeletons" $(C W 1,160)$, "the dead" $(C W 1,161)$, "dust [. . ] whirling with the dust" $(C W 1,161)$. As the lover, unheeding of the speaker's warnings, joins the ghostly procession, "Love passed into the house of Lust" $(C W 1,161)$. This poem's considerable force depends on the contrast between the observer, seeing things objectively from outside, and the people inside the house, who are too involved to realize how little autonomy they have. The alienating realization brought out by this defamiliarizing gaze is that people like oneself, who presumably view themselves as free agents, are as determined in their actions as any object-as bound to the convergence of external factors as William Wordsworth's dead Lucy, rotating along with the other things of the planet, or as iron filings heading towards a magnet. This experience throws a stark light on the subject's own sense of self, as, by observing others, he ends up intuiting that he, too, is a puppet. 
In the latter poem at least, the puppeteer is lust, conceived as something that takes control away from the subject (as in Shakespeare's sonnet 29, "The expense of spirit in a waste of shame," which Wilde admired). But the point is generalizable beyond that ambit: these poems depict a subject's sudden awareness of the dominion of necessity, and its emotional cost (anguish, refusal). Rather than performing a reductio ad absurdum, they approach this inside-outside dialectic dynamically, which suggests that even at the experiential level, albeit only in privileged, poetic moments, we can become conscious of how external determinants objectively work in and through us. By such processes of analogical self-objectification, the divide between inside and outside is bridged, though only exceptionally. Both this emphasis on the exceptional character of objective apprehension and the poems' implied yearning for escape prefigure Wilde's mature engagement with the specialness of the aesthetic.

\section{ART AND CAUSALITY: "THE CRITIC AS ARTIST"}

One nineteenth-century strand of Continental thought, the earliest and foremost representative of which was again Schopenhauer, regarded art as an antidote to our slavery to the law of cause and effect. In his work, most notably in The World as Will and Representation, Schopenhauer expounds his soft determinist conception of the universe as almost entirely ruled by the metaphysical entity he calls "the Will." This entity governs everything from physical processes to the human mind. For Schopenhauer, then, our actions are governed by necessity, but with one exception: the act of forsaking our individual will, which we can and should take freely. Although he holds that the only permanent way of prising freedom out of the jaws of necessity is to relinquish willing altogether through ascetism, he also identifies a provisional form of escape in the contemplation of art, during which one becomes a "pure, will-less subject of cognition." 39 When properly appraised, that is, art does not activate one's will by spurring one to action: we do not wish to jump onstage and warn Othello of Iago's deceit, or to have carnal knowledge of a beautiful Greek statue, or to eat the grapes in Caravaggio's "Basket of Fruit"; if we experience similar emotions through art, it is in a mental space that is somehow separated by the common run of causality. ${ }^{40}$ While Schopenhauer's foremost predecessor in this line of thinking, Immanuel Kant, does characterize art as a product of freedom that elicits disinterested appreciation in his Critique of Judgement, this concept only acquires 
its eschatological overtones of liberation from the world's suffering in Schopenhauer's work. ${ }^{41}$

This view of art as escape from the world's oppressive logic was to become an underpinning for nineteenth-century European aestheticisms. ${ }^{42}$ The narrator of Théophile Gautier's Mademoiselle de Maupin, for example, clings to the "outer outlines of things" represented by plastic art as a reaction to the feeling that his actions are "in accordance with common laws" rather than the result of "free will." The Renaissance Pater anguishes over "the intricacy, the universality of natural law, even in the moral order"; his advocacy of heightened sensation in his conclusion is presented as a corrective to this state of affairs. ${ }^{44}$ George Gissing's Schopenhauer-centered essay "The Hope of Pessimism" states that "[i]n the mood of artistic contemplation the will is destroyed, self is eliminated, the world of phenomena resolves itself into pictures of absolute significance, and the heart rejoices itself before images of pure beauty." 45 Friedrich Nietzsche, while mocking the idea of free will as "dragging yourself by your hair out of the swamp of nothingness into existence," also advocates an aestheticized version of the individual will for aristocratic dominators. ${ }^{46}$ Among these later writers (who were mostly influenced by more assertive ethical orientations such as individualism) Schopenhauer's dour ascetism tended to be jettisoned as an ideal for conduct, so art came to be regarded as the only viable path to freedom in an otherwise clockwork world.

Wilde's dialogue "The Critic as Artist" draws on this set of ideas to broach the problems of agency and perspective he had raised in the earlier poems. The dialogue's principal speaker, Gilbert, grounds the value of art on the possibility it opens for emancipation from the sordid necessity that governs the rest of our lives:

[Action] is a blind thing dependent on external influences, and moved by an impulse of whose nature it is unconscious. It is a thing incomplete in its essence, because limited by accident, and ignorant of its direction, being always at variance with its aim. . . It is the last resource of those who know not how to dream. $(C W 4,147)$

In the ordinary course of life, where "action" takes place, there is no freedom. If we feel, say, angry, it is only because we are made in such a way that this sentiment prompts us to action. This is how supra-personal biological, psychic and societal forces act through us 
(although we are typically not aware of this-that is why action is "ignorant of its direction" and "at variance with its aim"). On the other hand, if we experience a similar feeling while (for example) watching Othello, we have in a limited sense broken free of causality: we are angry, as it were, without good cause. ${ }^{47}$ This is why "[a]ll the arts are immoral, except those baser forms of sensual or didactic art that seek to excite to action of evil or of good. For action of every kind belongs to the sphere of ethics. The aim of art is simply to create a mood" $(C W 4,179)$. This is the closest we can get to freedom. "Emotion for the sake of emotion is the aim of art, and emotion for the sake of action is the aim of life, and of that practical organization of life that we call society" $(C W 4,174)$. Gilbert, then, agrees with Schopenhauer that art can (to a point) emancipate us from necessity, by dissolving impulses into a non-goal-oriented, contemplative mood. This anxiety about causality and the desire to meet the challenge of determinism by embracing a mode of experience cordoned off from the normal course of events jointly provide a largely overlooked rationale for Wilde's lifelong advocacy of the aesthetic life: "[W]hen a man acts, he is a puppet; when he describes, he is a poet" $(C W 4,177) .{ }^{48}$

But if the aesthetic may liberate us, it can also reveal the ways in which we are not free:

By revealing to us the absolute mechanism of all action, and so freeing us from the self-imposed and trammelling burden of moral responsibility, the scientific principle of Heredity has become, as it were, the warrant for the contemplative life. It has shown us that we are never less free than when we try to act. . . We may not watch it, for it is within us. We may not see it, save in a mirror that mirrors the soul. $(C W 4,177)$

Besides instancing Wilde's well-established indebtedness to contemporary science (and to Aristotle's ideal of the contemplative life), this quote has two major implications. One is that-as per the necessitarian argument-self-consciousness is not a reliable guide to understanding the action of the determinants acting upon us ("we may not watch it ... we may not see it"). Another is that artistic representation can bridge the gap between the subjective and the objective sphere. It is in this sense that the striking sentence about seeing the hidden workings of causality in "a mirror that mirrors the soul"-a supernatural prop to overcome our cognitive limitations-is realized in two of Wilde's fictions from these years, although in "Lord Arthur Savile's Crime" the mirror turns out to be the protagonist's hand and in The Picture of 
Dorian Gray a portrait. In both cases, such props are used to reflect on morally fraught situations.

\section{THE PROBLEM OF RESPONSIBILITY: “LORD ARTHUR SAVILE'S CRIME"}

Believing in free will justified, among other things, drawing a boundary between the world of the is and that of the ought: where determination ended, morality, and responsibility could begin. If indeterminism lacked a principled way of justifying the break between human will and the rest of the universe without resorting to a religious or idealistic parti pris, determinism was exposed to the scarcely less damaging accusation that it did away with personal responsibility and even ethics in general: simply put, if everything happened necessarily, there seemed to be no point in telling people how they ought to behave. William Hamilton's case for free will, for instance, is moral through and through: "The fact that we are free is given to us in the consciousness of an uncompromising law of Duty, in the consciousness of our moral accountability." ${ }^{49}$ Necessitarians, conversely, needed to stave off accusations of amoralism (to which the political radicalism prevalent among them rendered them particularly vulnerable), so they were often at pains to show that determinism did not conflict with ethics. ${ }^{50}$ Despite such attempts, not believing in Froude's "point of freedom" was still morally suspicious in 1884, when the American pragmatist William James rejected the outlook in question on the grounds that it tends to abolish personal responsibility: "It makes the goose flesh the murder excites in [one] a sufficient reason for the perpetration of the crime. It transforms life from a tragic reality into an insincere melodramatic exhibition, as foul or as tawdry as anyone's diseased curiosity pleases to carry it out." ${ }^{\text {"1 }}$ James's insistence in choosing words associated with Decadent and Naturalist literature (compounded by his association of determinism with "Parisian littérateurs" and the "roman naturaliste state of mind") is interesting in its own right, but my point here is that while for him determinism is not necessarily incorrect, the fact that it tends to undermine responsibility is a sufficient ground for rejecting it. ${ }^{52}$

The courtroom was an obviously suitable place to apply such lines of thinking. Then as now, Common Law-based jurisprudence postulates that our actions are, as a rule, the results of our free choices; this is why we can be held accountable for them. Reduced accountability is nonetheless contemplated in certain cases in which the individual is held not to have had the opportunity to choose freely: if the individual belongs to certain categories for whom choice is by definition impossible 
(minors, the mentally impaired); or if he or she was subjected to the effects of overwhelming circumstances at the time of committing the offence (coercion, compulsion and, in some legislations, strong emotion and altered states of consciousness). The question of which side of the "point of freedom" an individual case falls on can determine whether that individual is prosecutable for that criminal act; the problem is where and how to draw the line. The standard late-Victorian position was that of the prominent Benthamite jurist James Fitzjames Stephen, who in 1883 cut through this Gordian knot by asserting the primacy of stipulative definitions based on the practical needs of the law: "It is common to discuss this subject as if the law itself depended upon the result of discussions as to the freedom of the will, the origin of moral distinctions, and the nature of conscience. Such discussions cannot be altogether avoided, but in legal inquiries they ought to be noticed principally in order to show that the law does not really depend upon them." ${ }^{53}$ Whether or not the distinction between deliberateness and compulsion was metaphysically tenable, the law must uphold it.

Wilde's awareness of the essential arbitrariness of this legal distinction can be discerned in his distressingly unheroic attempt to obtain a reprieve on the grounds of insanity through a letter from prison that he sent to the Home Secretary in mid-1896. ${ }^{54}$ "The petition of the abovenamed prisoner humbly sheweth [here begins Wilde's wording] that he does not desire to attempt to palliate in any way the terrible offences of which he was rightly found guilty, but to point out that such offences are forms of sexual madness and are recognised as such not merely by modern pathological science but by much modern legislation." ${ }^{55}$ With this argument, and by further describing himself as a "prey" to "the most horrible form of erotomania" which "left [him] the prey of the most revolting passions," Wilde grounded his unsuccessful plea for clemency on the (likely disingenuous) suggestion that his "terrible offences" had been brought about by an irresistible compulsion rather than by deliberate volition. ${ }^{56}$ He couldn't have helped himself, as the phrase goes.

About a decade earlier, under immeasurably better personal circumstances, Wilde had proffered a more nuanced take on the boundary between deliberation and compulsion in his story "Lord Arthur Savile's Crime," subtitled "A Study of Duty." Aside from its light-hearted satirical relish in taking "duty," a mainstay of contemporary cant, and 
making it the guiding light of a character who is bent on a senseless course of murder, the story has a thoughtful undercurrent that explores the same problem that occupied James and his philosophical predecessors, namely the compatibility between determinism and ethics.

The main source of humor is the protagonist's intransigent interpretation of what he believes is his "destiny" (as revealed to him by the chiromantist Mr. Podgers) as his "duty." Podgers reads in Lord Arthur's hand that the latter is destined to commit a murder. The protagonist meditates on his destiny thus: "[H]e had become conscious of the terrible mystery of Destiny, of the awful meaning of Doom. . . . Were we no better than chessmen, moved by an unseen power, vessels the potter fashions at his fancy, for honour or for shame?"57 Although there is an element of comical melodrama in the tone of the young lord's musings as rendered through free indirect speech, the dilemma with which he is faced is a serious one: how is one to negotiate the knowledge (or belief) that one's future actions are predetermined? Lord Arthur's practical solution is to obey Hamilton's "uncompromising law of Duty" actively, by trying to kill first one, then another innocent relative of his, both selected for convenience of execution. Both attempts are frustrated, causing Lord Arthur to put off his wedding and sink into depression, until, while wandering along the Thames at night, he finds the chiromantist leaning on the balustrade, and kills him by pushing him into the river. Everything goes smoothly after this episode. The story closes on a depiction of Lord Arthur's family idyll, in which, in a final twist, it is revealed that the chiromantist was a charlatan.

At one level, "Lord Arthur Savile's Crime" is a good illustration of James's idea that determinism is a bad guide to conduct. The oddness of the protagonist's emotional economy is particularly telling. Lord Arthur is no psychopath: he tries to act justly towards his fiancée Sybil, whom he loves, and his feelings do not include an enjoyment of killing. He can even empathize with Lady Clementina, the relative he has tried to poison, hoping that no misfortune besides his own attempt at killing her has befallen her: "He began to be afraid that some accident had happened to her." ${ }^{\text {" }}$ "He takes the revelation of his destiny as a calamity that he must tackle bravely: "Ardently though he loved the girl . . . he recognized none the less clearly where his duty laid, and was fully conscious of the fact that he had no right to marry her until he had committed the murder."59 For all this inner uprightness, he attempts to kill, and later does kill innocent people without the slightest pang of remorse. What is missing from Lord Arthur's perception (and this black spot forms one of the story's main 
wellsprings of comedy) is a sense that what he does is immoral: he feels no sense of guilt towards those he tries to kill; no intimation that by choosing whom to kill, when and how to kill them and so on, he makes choices that are his own rather than pre-ordained; in short, no sense of personal responsibility. The effects of Lord Arthur's fatalism include the disappearance of his moral sense, or at least its erosion as far as those actions of his which he believes to be determined are concerned. Lord Arthur knows (or at least believes) that a future act of his must happen; but in order to fulfil his destiny he must still act in a way that is (or seems to him) deliberate. By believing that he is predestined to kill someone-he does not know whom-Lord Arthur energetically busies himself in killing someone-anyone will do; by taking his destiny as an injunction which he must take pains to fulfil, he invests the external determinations acting on him with an ethical significance ("duty") that they cannot have, if ethics is a set of rules dealing with how we ought (freely) to direct our actions. From this standpoint, he is clearly made into a worse person by his embrace of deterministic modes of thought.

The story, however, has a further twist, which becomes apparent when we ask whether destiny really exists in its world. So far I have assumed that the protagonist fulfills the prophecy out of his own free will by mistakenly believing that it is his duty to follow what (he believes) destiny has decided for him; if this is true, destiny does not exist, and Podgers was a charlatan. But on another and equally plausible reading, destiny exists, Podgers was no charlatan, he did indeed foresee Lord Arthur's destiny in the latter's hand, and this destiny included the ironic (and, for the chiromantist, horrific) twist that the person that Lord Arthur was meant to kill was Podgers himself. ${ }^{60}$ If so, Lord Arthur was indeed predestined to kill somebody, but did not know that the identity of his victim was as determined as the action itself. Whichever the case may be, the story suggests that, contra Bray and Mill, ethics and determinism are not compatible: destiny, if it exists, gnaws at the very foundations of ethics; however, contra James, this is no argument either for or against its existence. Here Wilde's willingness to follow paradox wherever it will lead-in this case, to narrative indeterminacy_-makes him part company with both sides. Determinism may be both immoral and true; responsibility an illusion, and yet desirable; ethics meaningless, yet necessary. These themes are explored at greater length in Wilde's only novel, which constitutes the most sustained and characteristic example of his literary way into this philosophical question. 
As is well known, the plot of The Picture of Dorian Gray consists of two interlocking strands: a non-supernatural one that concerns the moral trajectory of an initially naïve young man, who is made aware of more fulfilling modes of understanding and approaching life, and who, possibly as a result of this, ends up descending into mostly unspecified depths of immorality and degradation; and a supernatural one that concerns the magical portrait of him which reflects (and may, partly or wholly, cause) the unfortunate evolution of his soul. The two strands come together at the end, when by stabbing the portrait Dorian unwittingly kills himself.

The plot is accompanied by a sustained and, as will be seen, contradictory meta-commentary, which foregrounds narrative logic as a theme in its own right. Rather than keeping aloof from itself $\grave{a}$ la Madame Bovary, Wilde's novel is as saturated by competing interpretations of its own plot as its own publication sibling, The Sign of the Four. The main characters (Dorian Gray, Lord Henry Wootton, and Basil Hallward), as well as the narrator, continually comment on the story they inhabit, furnishing various interpretations of the significance of the story's facts. However, their perspectives are so incompatible that the overall effect is to create, rather, a series of ongoing questions, the resolution of which can prove quite a challenge for a philosophicallyminded reader: What exactly is the relationship between Dorian Gray and his portrait? Who or what is responsible for Dorian's descent into immorality and dissoluteness? Is there such a thing as a person's soul? Does the story have a moral at all, or should we take the Preface's arch dismissal of the matter seriously?61

These questions can all be considered facets of one overarching issue: what the central agency driving forward the plot is. This question of narrative logic, I argued in section II, was a pervasive preoccupation for nineteenth-century novelists, for whom it was (among other things) an artistic correlative of the problem of the freedom of the will. In this case, the novel's self-theorization draws together and expands many of the strands of thinking Wilde had been pursuing throughout his writings. If (assuming I am right about its authorship) with the roughly contemporaneous filings' story Wilde had crafted a pithy, deliberately "reduced to absurdity" parable about our actions not being our own, in his novel he circumvents the unwarranted simplifications of what he had called "necessitarianism in its crude form" by transferring the theme to a recognizably realistic fictional world. If "The Harlot's House" had lamented how lust can overrule one's better judgement, Dorian Gray 
is under the sway of a much more variegated array of determinants. If "The Critic as Artist" (also written at about the same time) had invoked a "mirror that mirrors the soul," partaking of some of the character of art, to overcome the entanglement in the passions that hinders the power of introspection to understand those determinants, this novel hinges on a supernatural artwork that becomes enigmatically entangled with the protagonist's agency. And if "Lord Arthur Savile's Crime" had complicated the relatively straightforward dyad of free will vs destiny, Dorian Gray's greater length allows for a more layered engagement with the problem of how an individual interacts with supra-subjective forces. I want to propose that asking, in a fairly literalist fashion, who or what is responsible for Dorian's downfall and death provides a way into the work's engagement with the general problem I have been pursuing: the implications of causality for human agency.

To begin with, there is no shortage of textual evidence for the interpretive category on which most recent scholarship has focused, namely scientific materialism and particularly the theory of heredity. In two famous passages we are told, respectively, that Dorian goes through a scientistic or Darwinist phase in which he "found a curious pleasure in tracing the thoughts and passions of men to some pearly cell in the brain, or some white nerve in the body, delighting in the conception of the absolute dependence of the spirit on certain physical conditions" $(C W 3,111)$; and that he wonders whether "some strange poisonous germ crept from body to body till it had reached his own" (CW3, 288), suggesting that his soul's afflictions, indeed his very impulse to utter the "mad prayer" that ties the portrait to his soul, are traceable to his ancestry. ${ }^{62}$ Several other passages invoke science, as many have noted. Standard scientistic determinism, thus, becomes part of the flavor of the novel and a plausible lens through which to view its plot.

However, this lens cannot provide a comprehensive account of the novel's reflections on itself. Its "science," for one thing, is often of a peculiar sort, mixed as it is with a patent supernaturalism, and with considerations that deliberately blur the line between the religious and the scientific worldview: "Soul and body, body and soul-how mysterious they were! . . . Who could say where the fleshly impulse ceased, or the physical impulse began? . . . The separation of spirit from matter was a mystery, and the union of spirit with matter was a mystery also" $(C W 3,219){ }^{63}$ This complicates the matter, as does the fact that a different form of influence is at work when it is suggested en passant that "Dorian Gray had been poisoned by a book" $(C W 3,289)$ - the French novel given to him by Lord Henry. According 
to this passage, the protagonist is corrupted not by his own hereditary taints, but by insalubrious reading. This harks back to a tradition of characterization that predates Positivism's application of science to phenomena of a higher or human order. ${ }^{64}$

Apart from "germs" and books, Dorian is also under the sway of other characters. With his charisma and his avowedly immoral passion for influencing people, Lord Henry's credentials as the story's Mephistopheles would seem strong. After his first "decadent" speech to Dorian, he sees "that a look had come into the lad's face that he had never seen there before" $(C W 3,183)$, and he later elaborates that "to a large extent [Dorian] was his own [Lord Henry's] creation" $(C W 3,218)$. Like Faust, Dorian, for his own part, is "dimly conscious that entirely fresh influences were at work within him. Yet they seemed to him to have come really from himself" $(C W 3,184)$. Whatever the case may be, it is hard to credit Lord Henry with determining the course of the story when towards the end he does not seem to understand his mentee at all; most notably, he thinks Dorian incapable of committing a murder.

A less obvious possibility for the decisive influence is the apparently prim Basil, who, at least initially, seems to regard the portrait as an emanation of his soul: "The reason why I will not exhibit this picture is that I am afraid that I have shown in it the secret of my own soul" $(C W 3,172)$. On a literal-minded reading, this means that he is in love with Dorian, but it is also possible to think of it more abstractly as some hidden psychic corruption that Dorian inherits. After murdering Basil, Dorian seems to be convinced that the painter had somehow been responsible for the portrait's supernatural qualities, as he tells Alan Campbell while compelling him to destroy the corpse: "You don't know what [Basil] had made me suffer. Whatever my life is, he has had more to do with the making or the marring of it than poor Harry has had. He may not have intended it, the result was the same" $(C W 3,308) .{ }^{65}$ But this idea of artist-to-subject influence turns out to be an inadequate description of the portrait's supernatural properties. Basil is unaware of them until Dorian shows him the portrait, whose altered brushwork Basil recognizes as his with a horrified shock.

One may be tempted to look for the culprit not among biological factors, or books, or people, but in the demonic agency of the portrait itself. This seems to be implied (though with a characteristically evasive "as though" wording) in the following scene, when the portrait elicits in Dorian the goal-oriented, emphatically non-artistic emotion of hatred, which prompts him to kill Basil while the latter is praying: 
"Dorian Gray glanced at the picture, and suddenly an uncontrollable feeling of hatred for Basil Hallward came to him, as though it had been suggested to him by the image on the canvas, whispered into his ear by those grinning lips" (CW3, 300). Unlike in the ambiguous "Lord Arthur Savile's Crime," the supernaturalism of Wilde's novel is unquestionable: following the famous prayer, the portrait somehow records the events taking place in Dorian's soul; but it is unclear whether the portrait is also an agent in its own right, pursuing its own inscrutable or Satanic ends, and effectively causing those events. While Dorian's hope that "[t]he portrait would be a guide to him through life" $(C W 3,250)$ is evidently a delusion, the suggestion that the portrait may affect him in a darker fashion is offered more than once: "Was there some subtle affinity between the chemical atoms, that shaped themselves into form and colour on the canvas, and the soul that was within him? Could it be that what that soul thought, they realized? that what it dreamed, they made true? Or was there some other, more terrible reason?" $(C W 3,249)$. The ominous final question suggests that "the fatal portrait to which all his misery had been due" $(C W 3,301)$ may have some conscious evil agency over Dorian's soul.

But (unsurprisingly at this point) this interpretation, too, must contend with conflicting textual evidence, beginning from Basil's reflections as his thought evolves into an impersonal aestheticism: "Form and colour tell us of form and colour-that is all. It often seems to me that art conceals the artist far more completely than it ever reveals him" $(C W 3,265)$. This both supports and is corroborated by the preface; and yet the portrait behaves in ways that are incompatible both with Wilde's Aestheticist creed and with the Schopenhauerian tradition of art as a means of reaching a self-contained experience that does not translate into action. Moreover, there is an ambiguity about Dorian's "soul" that is never solved over the course of the story, and is taken up again at other times, for example when Basil and Lord Henry bicker over Dorian's newly developed intractability: “This is your doing, Harry,' said the painter bitterly. Lord Henry shrugged his shoulders. 'It is the real Dorian Gray-that is all'" $(C W 3,190) .{ }^{66}$

This leaves one final hypothesis, namely that Dorian freely (if unwittingly) wills his destiny by voicing his prayer that the portrait may grow old while he stays young. "I would give my soul for that," he says, and God (or the Devil) apparently hears him. Wilde had been brought up as a Protestant, dallied with Catholicism as a young man, and although in his maturity he veered towards atheism, both in his novel and elsewhere ("The Fisherman and his Soul," for instance) 
he shows an abiding preoccupation with the Christian notion of the soul as something that can be cared for, corrupted, or bartered away. ${ }^{67}$ Towards the end of the novel Dorian expresses the belief that the soul is not, contra Lord Henry, a primitive myth, but "a terrible reality" $(C W 3,350)$; he is proven right in some sense, but he seems not to understand the exact nature of the portrait's relationship with his soul because he clearly does not realize that by stabbing the portrait he would kill himself. ${ }^{68}$ Thus, the Christian/indeterminist hypothesis is also strained.

It is the relentlessly contradictory quality of the novel's forays into self-theorization, for which established terms such as "interpretive openness or plurality" or even more outré ones such as "hypostatic multiplicity" can seem rather pallid, that I want to emphasize. ${ }^{69}$ The relationship between agency and causality is clearly a central concern for this novel, but if we were to take the latter as a philosophical apologue in the tradition of, say, Denis Diderot's Jacques le fataliste, the only coherent conclusion would seem to be that it does not know what it is about: interpersonal influence, supernatural conditioning, secular naturalism, the competing Christian doctrines of free will and predestination, suggestions of metempsychosis, and of some mystical intermingling between art and life, these explanations of the logic of the plot arc are all piled on, often in deliberately noncommittal language, and made to compete till the novel's famous finale, in which Dorian inadvertently kills himself by attempting to destroy the portrait. This is aesthetically satisfying, but it provides no hook for our philosophical reader to make sense of the tale. It seems that Dorian's downfall is the product of so many causes that the novel all but runs out of breath trying to enumerate them, while never making up its mind about their respective importance. What are we to make of this profusion of irreconcilable explanations?

\section{CONCLUSION}

To answer this question, let me take a broader view of my line of argument throughout this article. I have been presenting Wilde as an acute albeit unsystematic "living theorist," who began his adult life with an intellectual preoccupation in, and remained engaged in a literary negotiation of, a range of thorny and arguably unsolvable philosophical problems hinging on the freedom of the will. I have argued that the nature of his engagement with the problem, while influenced by the sciences, has a parallel philosophical genealogy, 
which is reflected in the following preoccupations: (a) whether mind is any freer than matter-Wilde tended to regard the distinction as moot; (b) to what extent we may consciously grasp the action of the determinants acting through us - only under certain circumstances, for example when we see ourselves through art; (c) whether art, apart from representing causality, can in some sense disrupt it-Wilde thought it could, at least in a localized way; (d) whether determinism and ethics can coexist-probably not, and yet the former is compelling and the latter necessary. These are all tendencies rather than univocal positions, expressed by dramatic presentation rather than by argument; and their import can shift quite markedly from one part of the oeuvre to the next, contradictoriness reaching its apogee in The Picture of Dorian Gray. Given the foregoing, I have two final points, one about content and one about form.

The first is that the conflicting nature of Wilde's pronouncements on the freedom of the will, highlighted at the beginning of this essay, is largely a function of their embeddedness in the humanistic/philosophical tradition. In this respect, one's choice of evidentiary framework has tangible interpretive consequences. While (social-) scienceoriented approaches (most notably the work of Nicholas Dames and Sally Shuttleworth, as well as most Wilde scholars cited above) have undoubtedly increased our understanding of the interconnectedness of the Victorian intellectual landscape, humanistic discourses were at least as likely as science was to influence writers' perceptions of broad existential issues such as this- there was, for example, an established tradition of philosophical necessitarianism that was largely unrelated to the sciences - so we ought to be cautious in equating determinism with the scientific worldview, or free will with the Republic of Letters. ${ }^{70}$

Moreover, there is a significant difference between the "two cultures" histories in this connection. The history of the lessons to be drawn from science arranges itself in a fairly linear progression away from free will in the prevalent nineteenth-century sense (that is, the ability to act in ways that transcend the convergence of suprasubjective determinants) and towards a generalization of the deterministic thesis from the realm of the physical into that of the human. ${ }^{71}$ In such a framework, it makes sense to regard Wilde as reacting in one way-accepting or hostile-to a history of progressive erosion of the idea of freedom, hence the two prevalent paradigms of the deterministic Wilde accepting the scientistic Zeitgeist and the libertarian Wilde reacting against it. Yet, however strong the influence of science on modern determinism, philosophers (or, for that matter, novelists, 
historians and jurists) did not "discover" what Martin Luther had called "the bondage of the will" sometime in the 1870s; nor did they simply convert en masse when science made this or that discovery. ${ }^{72}$ The history of this cluster of ideas in humanistic culture is a longer one and has been marked, instead, by a non-linear negotiation of competing needs - moral, political, emotional and aesthetic, as well as theoretical.

With this in mind, the simultaneous pull towards determinism and the ideal of liberty in Wilde's works can be regarded as a literary version of a millennia-old style of philosophical argument, namely the skeptic's refusal to force reality into commonly accepted schemes. As I hope to have shown, some of the ancient skeptics' ideas, namely that the nature of phenomena changes depending on the observer's perspective, or that equally valid contradictory explanations can account for a given phenomenon, structure Wilde's engagement with the freedom of the will. ${ }^{73}$ In contrast to, say, his nemesis Emile Zola (who aimed to "apply" determinism to fiction), Wilde does not set out to illustrate a specific worldview through fiction. Rather, like a good skeptic, he punctures the element of arbitrariness at the heart of thinking, the unjustified beliefs that ground justified beliefs-making Truth dance on the tightrope, as Lord Henry has it. Thus, the contradictoriness of Wilde's thought on one level is, on another, a representation of how the plurality of our modes of engagement with reality challenges the streamlining tendencies of philosophical and scientific theory-making alike.

This leads me back to The Picture of Dorian Gray, and to the second and final point, which is that the form of Wilde's works shapes and qualifies their philosophical (or "living-theoretical") content. ${ }^{74} \mathrm{In}$ its simultaneous invocation and undermining of the cause-seeking mindset, Wilde's novel is a prime example of skepticism in action; but if Wilde partook of an ancient attitude, he mediated it through stylistic modes that were specific to his era, genre, and the subset of literary culture he both inherited and helped shape. Foremost among these is the pursuit of narrative indeterminacy, implemented in his novel by a dialogism very nearly approaching the non-hierarchical multiplicity of perspectives that Mikhail Bakhtin famously detects in Fyodor Dostoevsky's works. ${ }^{75}$ Indeed, the famous idea from "The Truth of Masks" that "a truth in art is that whose contradictory is also true" is a memorable expression of Bakhtin's principle, as well as an excellent description of The Picture of Dorian Gray (CW4, 228). It is a radicalization of the novelistic logic of both/and that permits the coexistence in Wilde's novel of elements that the either/or logic 
of expository prose (be it philosophical or scientific) would place on opposite sides of a barricade. Whether in complicating the relationship between body and soul, or making different forms of causation clash, or implying incompatible conceptions of the role of art, or being at the same time a moral and an immoral book, Wilde's novel grounds all these skeptical innovations in "living theory" on formal means connected to the new aesthetic ideal of literature as alternative and irreducible to expository forms of discourse. ${ }^{76}$

This, in turn, has implications for how we approach his works today. Recent scholarship has had the merit of establishing once and for all that Wilde was engaged with a wide range of the intellectual currents of his own day; what has not, to my mind, been evidenced to the same degree is a recognition of the refractoriness that his works present to the disambiguating tendencies of second-degree discourse, which includes criticism. Not the least of the ways in which Wilde's "theory" is "living" is that for almost every generalization we may be tempted to offer about his writings, a qualification presents itself. However, as I have been suggesting, this formal richness should not be a problem for criticism, but an opportunity to use what Carolyn Lesjak calls the "movement between positions that Wilde's thinking activates" to harness the distinctive power of the literary to go beyond the terms of our thinking. ${ }^{77}$

\section{Bilkent University, Ankara}

\section{NOTES}

This article has required a very great deal of scrubbing, squeezing, and ironing. My thanks to Patrick Fessenbecker of Bilkent University and to several anonymous reviewers for helping me shape my arguments at various stages.

${ }^{1}$ Oscar Wilde, "The Soul of Man" in The Complete Works of Oscar Wilde, Vol. 4: Criticism: "Historical Criticism," "Intentions," "The Soul of Man," ed. Josephine Guy (Oxford: Oxford Univ. Press, 2007), 238. Hereafter cited parenthetically by page number and abbreviated CW4.

${ }^{2}$ Philip E. Smith and Michael S. Helfand, Oscar Wilde's Oxford Notebooks: A Portrait of Mind in the Making (Oxford: Oxford Univ. Press, 1989), 141.

${ }^{3}$ David Hume, Enquiries Concerning the Human Understanding and Concerning the Principles of Morals, ed. L. A. Selby-Bigge and P. H. Nidditch (Oxford: Clarendon Press, 1975), 95.

4 "You should revolt against the luxury of riches and the tyranny of materialism [because] you will find the independence of art is the perfect expression of freedom." Oscar Wilde, "The Decorative Arts" in The Complete Works of Oscar Wilde, ed. J. B. Foreman (London: Collins, 1966), 935. A more Victorian-sounding variation on this is contained in a notebook entry on "Necessity," which begins with an extended quotation from Pater's "Winckelmann" (1867). Wilde continues as follows: "We are indeed compassed by the high uno'erleaped mountains of necessity, but for him who 
knows his limitations this dark horizon becomes the sunlit circle of duty." Smith and Helfand, Oxford Notebooks, 171.

${ }^{5}$ Oscar Wilde, The Complete Letters of Oscar Wilde, ed. Merlin Holland and Rupert Hart-Davis (New York: Henry Holt and Co., 2000), 689.

6 "Life is not governed by will or intention. Life is a question of nerves, and fibres, and slowly built-up cells in which thought hides itself and passion has its dreams." The Complete Works of Oscar Wilde, Vol. 3: "The Picture of Dorian Gray": The 1890 and 1891 Texts (Oxford: Oxford University Press, 2005), 351. Hereafter cited parenthetically by page number and abbreviated $C W 3$. Oscar Wilde, "Epistola: In Carcere et Vinculis" in The Complete Works of Oscar Wilde, Vol. 2: "De Profundis'; Epistola: In Carcere et Vinculis," ed. Ian Small (Oxford: Oxford Univ. Press, 2005), 62. Wilde, Complete Letters, 1128. Originally in a letter to Robert Ross, circa 3 January 1899.

${ }^{7}$ See Terri A. Hasseler, “The Physiological Determinism Debate in Oscar Wilde’s The Picture of Dorian Gray," Victorian Newsletter 84 (1993): 31-35; Michael Wainwright, "Oscar Wilde, the Science of Heredity, and The Picture of Dorian Gray," English Literature in Transition, 1880-1920 54.4 (2011): 494-522; Carolyn Lesjak, "Oscar Wilde and the Art/Work of Atoms," Studies in the Literary Imagination 43.1 (2010): 1-26; and Caroline Sumpter, "Oscar Wilde, Aesthetics, and Moral Evolution," Victorian Literature and Culture 44.3 (2016): 623-40.

${ }^{8}$ Terry Eagleton, Heathcliff and the Great Hunger: Studies in Irish Culture (London: Verso, 1995), 331.

${ }^{9}$ Roger Smith, Free Will and the Human Sciences in Britain, 1870-1910 (London: Routledge, 2016), 42.

${ }^{10}$ Wilde, Oxford Notebooks, 97.

${ }^{11}$ Bruce Haley, "Wilde's 'Decadence' and the Positivist Tradition," Victorian Studies 28.2 (1985): 229. The argument that Wilde reacted against scientistic determinism is also put forward in Andrew R. Morris, "Oscar Wilde and the Eclipse of Darwinism: Aestheticism, Degeneration, and Moral Reaction in Late-Victorian Ideology," Studies in History and Philosophy of Science 24.4 (1993): 513-40.

${ }^{12}$ Elisha Cohn, "'One Single Ivory Cell': Oscar Wilde and the Brain," Journal of Victorian Culture 17.2 (2012): 185-86. A similar argument is sketched, but not developed, in Christine Ferguson, "Oscar Wilde, 'The Critic as Artist' (1891)," Victorian Review 35.1 (2009): 64-68.

${ }^{13}$ On Wilde's indebtedness to ancient thought see in particular Iain Ross, Oscar Wilde and Ancient Greece (Cambridge: Cambridge Univ. Press, 2012); and Marylu Hill, "Wilde's New Republic: Platonic Questions in Dorian Gray," in Oscar Wilde and Classical Antiquity, ed. Kathleen Riley, Alastair J. L. Blanshard, and Iarla Manny (Oxford: Oxford Univ. Press, 2018), 231-49.

${ }^{14}$ On the growing distance between the "two cultures" see Ian Small, Conditions for Criticism: Authority, Knowledge, and Literature in the Late Nineteenth Century (Oxford: Clarendon Press, 1991), 31-88.

${ }^{15}$ See Smith, Free Will and the Human Sciences and Ian Hacking, "NineteenthCentury Cracks in the Concept of Determinism," Journal of the History of Ideas 44.3 (1983): 455-75.

${ }^{16}$ See John R. Reed, Victorian Will (Athens: Ohio Univ. Press, 1989).

${ }^{17}$ For a medically knowledgeable biographical analysis of Wilde's propensity to substance addiction, see J. F. Wrenne, "Oscar the Addict. Part 1: An Occupation of Some Kind," The Wildean 46 (2015): 21-52.

${ }^{18}$ Wilde, Oxford Notebooks, 109

${ }^{19}$ Wilde, Oxford Notebooks, 154. 
${ }^{20}$ The chief discussion of Wilde's plagiarism in this essay is Josephine Guy's editorial commentary in CW4, 274-360. More sources are included in Oscar Wilde's Historical Criticism Notebook, ed. Philip E. Smith (Oxford: Oxford Univ. Press, 2016), which also briefly discusses the question of whether Wilde actually submitted the essay, which is qualified as "undecidable" (xvi); and in Giles Whiteley, "Wilde’s Plagiarism in the Essay on 'Historical Criticism'," Notes and Queries 64.1 (2017): 139-41.

${ }^{21}$ This contrasts with the compatibilist strain prevalent in modern analytic philosophy, wherein causality and moral freedom are regarded as compatible. Perhaps the most influential statement of the position is Harry Frankfurt, "Alternate Possibilities and Moral Responsibility,” Journal of Philosophy 66.23 (1969): 829-39.

${ }^{22}$ Including only book-length works published over the past quarter-century: Julia Prewitt Brown, Cosmopolitan Criticism: Oscar Wilde's Philosophy of Art (Charlottesville: Univ. of Virginia Press, 1997); Bruce Bashford, Oscar Wilde: The Critic as Humanist (Madison: Farleigh Dickinson Univ. Press, 1999); Giles Whiteley, Oscar Wilde and the Simulacrum: The Truth of Masks (Oxford: Legenda, 2015); and Philosophy and Oscar Wilde, ed. Michael Y. Bennett (London: Palgrave Macmillan, 2017).

${ }^{23}$ See Amanda Anderson, "Living Theory: Personality and Doctrine in Eliot," in A Companion to George Eliot, ed. Amanda Anderson (Oxford: Wiley Blackwell, 2013), 442-56.

${ }^{24}$ This "libertarianism" is no relation to the political concept. The issue is complicated by the further division between compatibilism and incompatibilism, but this is not relevant to my argument. More generally, the relevant philosophical literature is vast. I have found Bernard Berofsky's Determinism (Princeton, Princeton Univ. Press, 1971) and his edited collection Free Will and Determinism (New York: Harper and Row, 1966) particularly useful.

${ }^{25}$ James A. Froude, “Spinoza,” Westminster Review 64 (1885): 20.

${ }^{26}$ For Post-Tridentine Catholic doctrine the will is free, hence the importance of good works for salvation. While earlier versions of Protestant theology such as Calvinism had hinged on de facto deterministic concepts such as providence and predestination, the Anglican doctrine of grace current by Victorian times and enshrined in Article X of the Church of England was notably less definite on this point.

${ }^{27}$ John Stuart Mill, The Collected Works of John Stuart Mill, Vol. 9: William Hamilton's Philosophy, ed. John N. Robson (Ann Arbor: Univ. of Michigan Press, 2006), 447.

${ }^{28}$ See Baruch Spinoza, The Ethics and Selected Letters, ed. Seymour Feldman, trans. Samuel Shirley (London: Hackett, 1982), 250. A formal exposition of Spinoza's broader point is found in the same volume at 57-62 in the appendix to part 1 of the Ethics.

${ }^{29}$ See Arthur Schopenhauer, Prize Essay on the Freedom of the Will, ed. Günter Zöller, trans. Eric F. J. Payne (Cambridge: Cambridge Univ. Press, 2003), 36-37.

${ }^{30}$ Richard Le Gallienne, The Romantic '90s (Garden City: Doubleday, Page \& Company, 1925), 254-56.

${ }^{31}$ The story will be included in the annotated bibliography of the Unpublished, Incomplete, \& Miscellaneous Works volume of the Oxford English Texts Complete Works of Oscar Wilde (in preparation as of September 2020), but will not be printed in full. I thank co-editor Rebecca D. Mitchell of the University of Birmingham for sharing some insights into the relevant editorial plans. For a parallel to this story, see chapter 3 of The Picture of Dorian Gray, where Lord Henry's dazzling table conversation has a similarly magnetic $(C W 3,204-5)$ effect on his listeners.

${ }^{32}$ James Boswell, Life of Johnson, 2 vol., ed. G. B. N. Hill and L. F. Powell (Oxford: Oxford Univ. Press, 1934), 2:92. 
${ }^{33}$ For a clear exposition of the issue see Stuart Hampshire, Freedom of the Individual (Princeton: Princeton Univ. Press, 1975), 104-12.

${ }^{34}$ William Hamilton, Lectures on Metaphysics and Logic, 2 vol., ed. Henry Longueville Mansel and John Veitch (Edinburgh and London: Blackwood, 1859-60), 2:152-74.

${ }^{35}$ Froude, 20.

${ }^{36}$ Charles Bray, The Philosophy of Necessity; or, The Law of Consequences; as Applicable to Mental, Moral, and Social Science, 2 vol. (London: Longman and others, 1841), 1:5.

${ }^{37}$ Henry Thomas Buckle, History of Civilization in England, 2 vol. (London: J. Parker and others, 1857), 1:18.

${ }^{38}$ Wilde, "Helas!" in Oscar Wilde, The Complete Works of Oscar Wilde, Vol. 1: Poems and Poems in Prose, ed. Bobby Fong and Karl Beckson (Oxford: Oxford Univ. Press, 2000), 156. Henceforward abbreviated $C W 1$ and cited parenthetically by line or page number.

${ }^{39}$ Arthur Schopenhauer, The World as Will and Representation, ed. Christopher Janaway, ed. and trans. Judith Norman and Alistair Welchman (Cambridge: Cambridge Univ. Press, 2010), 219.

${ }^{40}$ See Schopenhauer, The World as Will and Representation, 219-24.

${ }^{41}$ See Immanuel Kant, Critique of Judgement, ed. and trans. Werner Pluhar (Indianapolis: Hackett, 1987), 44-46.

${ }^{42}$ For an analysis of Schopenhauer's influence on the later history of art and philosophy, and in particular of his complication of Kant's ideal of disinterestedness, see Whitney Davis, Queer Beauty: Sexuality and Aesthetics from Winckelmann to Freud and Beyond (New York: Columbia Univ. Press, 2010), 83-98.

${ }^{43}$ Théophile Gautier, Mademoiselle de Maupin (Paris: Charpentier, 1876), 248-49. My translation.

${ }^{44}$ Walter Pater, The Renaissance: Studies in Art and Poetry, ed. Donald L. Hill (Berkeley: Univ. of California Press, 1980), 184-85.

${ }^{45}$ George Gissing, Essays and Fiction, ed. Pierre Coustillas (Baltimore: Johns Hopkins Univ. Press, 1970), 95. For a discussion of Gissing's indebtedness to Schopenhauer, see David Grylls, "Determinism and Determination in Gissing," Modern Language Quarterly 45 (1984): 61-84.

${ }^{46}$ Friedrich Nietzsche, Beyond Good and Evil: Prelude to a Philosophy of the Future, ed. and trans. Marion Faber (Oxford: Oxford World’s Classics, 2009), \$21.

${ }^{47} \mathrm{~A}$ very similar point is made by Leslie Stephen in The Science of Ethics (Freeport: Books for Libraries Presses, 1972), 320.

${ }^{48}$ Here I expand and qualify Lindsay Wilhelm's claim that Wilde "envisions art as a form of resistance against the biological and physical forces that dictate day-to-day existence" ("Sex in Utopia: The Evolutionary Hedonism of Grant Allen and Oscar Wilde," Victorian Literature and Culture 46.2 [2018]: 412).

${ }^{49}$ Hamilton, 2:412-13.

${ }^{50}$ For example, Bray, The Philosophy of Necessity, esp. 1:176-92. Another example is Mill's compatibilist philosophy of retributive justice, which transfers responsibility to the ambit of action rather than intention.

${ }^{51}$ William James, "The Dilemma of Determinism," in The Will to Believe: And Other Essays in Popular Philosophy (London: Longmans, 1910), 178.

${ }^{52}$ William James, 178.

${ }^{53}$ James Fitzjames Stephen, A History of the Criminal Law of England, 2 vol. (Cambridge: Cambridge Univ. Press, 2014), 2:96. 
${ }^{54}$ For a history of the insanity plea, see Nigel Walker, Crime and Insanity in England (Edinburgh: Edinburgh Univ. Press, 1968).

${ }_{55}^{5}$ Wilde, Complete Letters, 656. Originally in a letter to the Home Secretary, 7 February 1896. A number of similar pleas coming from Reading Gaol, some of them successful, are examined in Peter Stoneley, “Looking at the Others': Oscar Wilde and the Reading Gaol Archive," Journal of Victorian Culture 19.4 (2014): 457-80.

${ }^{56}$ Wilde, Complete Letters, 657.

${ }^{57}$ Oscar Wilde, The Complete Works of Oscar Wilde, vol. 8: The Short Fiction: "A Fire at Sea," "The Happy Prince and Other Tales," "Lord Arthur Savile's Crime and Other Stories," "A House of Pomegranates," "The Incomparable and Ingenious Story of Mr W.H.," "The Portrait of MrW.H.," ed. Ian Small (Oxford: Oxford Univ. Press, 2017), 57. Hereafter abbreviated CW8.

${ }^{58} \mathrm{CW} 8,67$.

${ }^{59} \mathrm{CW} 8,62$.

${ }^{60}$ This would explain Podgers's intense agitation while and after reading Lord Arthur's hand.

${ }^{61}$ This last question is elegantly addressed in John G. Peters, "Style and Art in Wilde's The Picture of Dorian Gray: Form as Content,” Victorian Review 25.1 (1999): 1-13.

${ }^{62}$ I discuss the definitive 1891 version.

${ }^{63}$ Also CW3, 258: "Might not things external to ourselves vibrate in unison with our moods and passions, atom calling to atom in secret love or strange affinity?"

${ }^{64}$ Jane Austen's Catherine Morland and Marianne Dashwood and Stendhal's Julien Sorel come to mind.

${ }^{65}$ Before the murder, Dorian makes much the same point to Basil: "You have had more to do with my life than you think." (CW3, 297)

${ }^{66}$ Later in the story Dorian reiterates this ambiguity when he muses that "Basil would have helped him to resist Lord Henry's influence, and the still more poisonous influences that came from his own temperament." (CW3, 269)

${ }^{67}$ Whether having a soul implies free will is also unclear. "Why had he been made like that? Why had such a soul been given to him?" (CW3, 246, emphasis added). "He felt that the time had really come for making his choice. Or had his choice already been made? Yes, life had decided that for him-life, and his own infinite curiosity about life" $(C W 3,257)$. Wilde repeats the idea in "De Profundis" $(C W 2,163)$.

${ }^{68}$ An ambiguity between the respective identities of Dorian and the portrait is established early on: "Mr Gray," says Lord Henry, "come over and look at yourself." $(C W 3,188)$ Dorian also tells Basil that he is "in love with [the portrait] . . It is part of myself. I feel that." (CW3, 192)

${ }^{69}$ Respectively: Studying Oscar Wilde: History, Criticism, and Myth, ed. Josephine Guy and Ian Small (Greensboro: ELT Press, 2006), 165; and Michael Patrick Gillespie, "Picturing Dorian Gray: Resistant Readings in Wilde's Novel," English Literature in Transition, 1880-1920 35.1 (1992): 7-25, esp. 23.

${ }^{70}$ And, a fortiori, the former with conservatism and the latter with progressivism. Compare Regenia Gagnier, "Freedom, Determinism and Hope in Little Dorrit: A Literary Anthropology," Partial Answers: Journal of Literature and the History of Ideas 9.2 (2011): 331-46.

${ }^{71}$ It has been argued that the new notions of indeterminacy produced by twentiethcentury physics have reinstated an element of chance into the mechanistic model of causation, but objections have been raised against the legitimacy of extrapolating observations made at the subatomic level and apply them to the visible world. 
For an argument to this effect, see Carl Hoefer, "Causal Determinism," Stanford Encyclopaedia of Philosophy (23 January 2003), https://plato.stanford.edu/entries/ determinism-causal/\#QuaMec. In any case, chance is not assimilable to freedom in the nineteenth-century sense of transcending causality.

${ }^{72}$ See Martin Luther, De Servo Arbitrio (Wittenberg, 1525). On Victorian philosophers' resistance to scientific determinism, see for example Smith, Free Will and the Human Sciences, esp. 1-16 and 82-91.

${ }^{73}$ The main figures of Pyrrhonic skepticism I have in mind are Aenesidemus, deviser of the "Ten Modes" or tropes for putting aspects of reality into opposition, and Agrippa's similar "five modes." The main source for ancient Greek skepticism is Sextus Empiricus, Outlines of Pyrrhonism, ed. and trans. R. G. Bury (Cambridge: Harvard University Press, 1933).

${ }^{74}$ For a sophisticated theoretical analysis of the relationship between form and content (not all of whose details I necessarily agree with), see Patrick Fessenbecker, Reading Ideas in Victorian Literature: Literary Content as Artistic Experience (Edinburgh: Edinburgh Univ. Press, 2020). The volume is in press as I write (October 2020); I thank the author for letting me access this work in advance of publication.

${ }^{75}$ See Mikhail Bakhtin, Problems of Dostoevsky's Poetics, ed. and trans. Caryl Emerson (Manchester: Manchester Univ. Press, 1984).

${ }^{76}$ I have examined the critical climate that drew Wilde to this formal slipperiness in Andrea Selleri, "Oscar Wilde and Authorialism," Authorship 3.2 (2014), online. Also in my book The Author in Victorian Literary Culture, in progress.

${ }^{77}$ Lesjak, 11. I borrow the latter expression from Andrew Dean, "Double Thoughts: Coetzee and the Philosophy of Literary Criticism," in Beyond the Ancient Quarrel: Literature, Philosophy, and J. M. Coetzee, ed. Patrick Hayes and Jan Wilm (Oxford: Oxford Univ. Press, 2017), 69. 